\title{
SUKUK NEGARA SEBAGAI PENDORONG PERTUMBUHAN PASAR KEUANGAN SYARIAH INDONESIA
}

\author{
Zuraidah \\ Fakultas Ekonomi Universitas Islam Negeri Maulana Malik Ibrahim Malang \\ Jl. Gajayana No. 50 Malang \\ e-mail : ida.zuraidah94@yahoo.com \\ HP. 081233070403
}

\begin{abstract}
Financiers expect the presence of Sukuk or Islamic State Securities driving growth of Islamic financial markets, especially in Indonesia. In addition, as one of the state budget funds, Sukuk also have a strategic role for the government as a benchmark of Islamic financial instruments. State Sharia Securities (SBSN) or can also be called Sukuk Company will publish SBSN is a company specifically formed for the purpose of publishing this SBSN (special-purpose vehicle SPV). SBSN or Sukuk this state is an instrument of debts without usury as in bonds, in which the Sukuk is issued based on a reference asset in accordance with Islamic principles. Sukuk may be used as an alternative to institutional investors such as banks, pension funds, and insurance also can invest surplus funds that had invested only in stocks, mutual funds, Seritifikat Bank Indonesia (SBI).
\end{abstract}

Key word: Sukuk, keuangan syariah, surat berharga syariah Negara

Sukuk / obligasi syariah ini bukan merupakan istilah yang baru dalam sejarah Islam. Istilah tersebut sudah dikenal sejak abad pertengahan, dimana umat Islam menggunakannya dalam konteks perdagangan internasional. Sukuk merupakan bentuk jamak dari kata sakk yang memiliki arti yang sama dengan sertifikat atau note. Ia dipergunakan oleh para pedagang pada masa itu sebagai dokumen yang menunjukkan kewajiban finansial yang timbul dari usaha perdagangan dan aktivitas komersial lainnya. Namun demikian, sejumlah penulis Barat yang memiliki concern terhadap sejarah Islam dan bangsa Arab, menyatakan bahwa sakk inilah yang menjadi akar kata "cheque" dalam bahasa latin, yang saat ini telah menjadi sesuatu yang lazim dipergunakan dalam transaksi dunia perbankan kontemporer.(Iswahjudi, 2004)

Dalam perkembangannya, the Islamic Jurispudence Council (IJC) kemudian mengeluarkan fatwa yang mendukung berkembangnya Sukuk. Hal tersebut mendorong Otoritas Moneter Bahrain (BMA - Bahrain Monetary Agency) untuk meluncurkan saham Sukuk berjangka waktu 91 hari dengan nilai 25 juta dolar AS pada tahun 2001. Kemudian Malaysia pada tahun yang sama meluncurkan Global Corporate Sukuk di pasar keuangan Islam internasional. Inilah Sukuk global yang pertama kali muncul di pasar internasional. (Indrawati, 2007)

Obligasi Syariah (Sukuk) adalah suatu surat berharga jangka panjang berdasarkan prinsip syariah yang dikeluarkan emiten kepada pemegang obligasi syariah yang mewajibkan emiten untuk membayar pendapatan kepada pemegang obligasi syariah berupa bagi hasil/margin/fee, serta membayar kembali dana obligasi pada saat jatuh tempo. (Fatwa DSN N0. 32/DSN-MUI/IX/2002). 
Lembaga keuangan Syariah yang pertama muncul di Indonesia adalah Bank Syariah yang ditandai dengan berdirinya Bank Muamalat pada tahun 1992, kemudian diikuti dengan produk pasar modal yaitu Obligasi Syariah dan Saham berbasis syariah diiringi peluncuran Jakarta Islamic Index (JII), disusul dengan Reksadana Syariah, juga lembaga lain seperti Asuransi Syariah (Asuransi Takafu pada tahun 1994).

Sukuk / Obligasi syariah berbeda dengan obligasi konvensional. Semenjak ada konvergensi pendapat bahwa bunga adalah riba, maka instrumen-instrumen yang punya komponen bunga (interest-bearing instruments) ini keluar dari daftar investasi halal. Karena itu, dimunculkan alternatif yang dinamakan obligasi syariah. Merujuk kepada Fatwa Dewan Syari'ah Nasional No: 32/DSNMUI/IX/2002, "Obligasi Syariah adalah suatu surat berharga jangka panjang berdasarkan prinsip syariah yang dikeluarkan Emiten kepada pemegang obligasi syariah yang mewajibkan Emiten untuk membayar pendapatan kepada pemegang obligasi syariah berupa bagi hasil/margin/fee, serta membayar kembali dana obligasi pada saat jatuh tempo". Pada awalnya, penggunaan istilah "obligasi syariah" sendiri dianggap kontradiktif. Obligasi sudah menjadi kata yang tak lepas dari bunga sehingga tidak dimungkinkan untuk di- syariah-kan.

Obligasi syariah sebagai bentuk pendanaan (financing) dan sekaligus investasi (investment) memungkinkan beberapa bentuk struktur yang dapat ditawarkan untuk tetap menghindarkan pada riba. Berdasarkan pengertian tersebut, obligasi syariah dapat memberikan : (1) Bagi Hasil berdasarkan akad Mudharabah/Muqaradhah/Qiradh atau Musyarakah. Karena akad Mudharabah/Musyarakah adalah kerja sama dengan skema bagi hasil pendapatan atau keuntungan, obligasi jenis ini akan memberikan return dengan penggunaan termindicative/expected return karena sifatnya yang floating dan tergantung pada kinerja pendapatan yang dibagihasilkan. (2) Margin/Fee berdasarkan akad Murabahah atau Salam atau Istishna atau Ijarah. Dengan akad Murabahah/Salam/ Isthisna sebagai bentuk jual beli dengan skema cost plus basis, obligasi jenis ini akan memberikan fixed return. (Majalah Modal, 2004)

Obligasi dan saham syariah merupakan surat berharga yang diterbitkan oleh perusahaan yang kegiatan operasionalnya berbasis Syariah dan struktur surat berharganya harus sesuai dengan prinsip syariah. Obligasi Syariah atau Islamic Bond, juga dikenal dengan sebutan Sukuk. Jadi Sukuk merupakan surat berharga (sekuritas) yang harus patuh kepada prinsip syariah baik aspek akad maupun penerapanya. Maka, dalam penerapanya tidak menggunakan sistem bunga karena hal itu merupakan riba, namun akadnya pun harus sesuai dengan prinsip syariah. (Fatwa DSN, 2004) 


\section{Perkembangan Obligasi Syariah (Sukuk) di Indonesia}

Yang pertama kali diterbitkan di Indonesia yakni Obligasi Syariah Mudharabah Indosat pada tahun 2002. Obligasi ini memiliki rating $\mathrm{AA}^{+}$dengan nilai emisi sebesar Rp 175 Milyar dengan jatuh tempat (maturity date) pada tanggal 6 November 2007 serta perkiraan return 16,38\% pada saat diterbitkan, Obligasi Syariah Mudharabah Indosat ini mengalami oversubscribe mengindikasikan tingginya permintaan akan Obligasi Syariah ini.

Dari tahun 2002 sampai tahun 2007, Indonesia telah menerbitkan 17 obligasi syariah yang didasarkan pada dua tipe akad yaitu prinsip Mudharabah dan Ijarah dengan total nilai sebesar 2,209 trilyun (Majalah modal, 2004).

Tanggapan pasar terhadap Sukuk juga semakin baik, jauh meningkat dibandingkan saat Sukuk negara pertama kali diterbitkan tahun 2008. Total Sukuk yang diterbitkan negara sampai saat ini mencapai Rp 116,69 triliun, dengan outstanding Rp 102,88 triliun atau setara dengan 11,9 miliar dollar AS. "Penerbitan Sukuk negara merupakan instrumen alternatif syariah untuk mempercepat pertumbuhan institusi syariah di Indonesia," kata Dahlan Siamat, Direktur Keuangan Syariah Kementerian Keuangan, dalam seminar internasional syariah di Bandung, Selasa (8/5). Dalam seminar yang diselenggarakan BI itu, Dahlan memaparkan, mayoritas Sukuk negara berupa Sukuk dana haji dengan nilai Rp 37,31 triliun, diikuti Sukuk ritel Rp 34,55 triliun.(Kompas Kamis, 10 Mei 2012)

\section{Animo Masyarakat Terhadap Penerbitan Sukuk}

\begin{tabular}{|c|c|c|c|c|c|c|c|c|}
\hline Jenis & Diterbitikan & Jatulu Tempo & Kupon & Milai Penerbitan & Demand & Listing & Harga hari Pertzma & Ratio \\
\hline 28001 & D9-Ang-V06 & $09-A u g=0 ?$ & & $\operatorname{Rp} 32833.650 .0000 .000$ & Rp33.83650000000000 & 10-Hug-V6] & 101,17500\% & $116,8 \%$ \\
\hline ORl1002 & $28-\mathrm{Ha}-07$ & $|a|-1 \mid$ & $9,28 \%$ & Rp 6.233.2000000000 & $\operatorname{Rp} 62688.3000000000$ & 29-Har-07]| & $72100 \%$ & $100,6 \%$ \\
\hline ORl1003 & $|12 . \operatorname{sep}-07|$ & 12:-sep-11 & $9,40 \%$ & Rpp9.367.695.000.000 & Rpp:.452.615.000.000 & 13-Har-09] & 100,85000\% & $100,9 \%$ \\
\hline Orloou & 12-1/ar-108 & 12-1-Mr-12: & $9,50 \%$ & Rpp13.455.765.000000 & Rp 113.559.395.0000000 & 13-Mar-108| & $0,17500 \%$ & $100,8 \%$ \\
\hline ORl1005 & $03-\operatorname{sep}-18$ & $15-\operatorname{sep}-12$ & $\mid 11,45 \%$ & Rp2.714 & Rp2.714.885.000.000 & $04.9 p-188$ & $100,25000 \%$ & $100,0 \%$ \\
\hline ORloob & 12-4ug-19] & 15-Avg-12. & $9,35 \%$ & Rp 0.536 & Rpp.5666.625.000.000 & 13-4ug-09] & 100,00000\%s & $100,4 \%$ \\
\hline SRO01 & $25-F e n-09$ & $25-F e b-12$ & $1200 \%$ & $\operatorname{Rp} 1.770 .000 .000 .000$ & Rp5.556.200.0000000 & 26 - Fen- -99 & $100,00000 \%$ & $313,9 \%$ \\
\hline SR002 & 10-Feb-10 & 10-Feb-1: & $8,70 \%$ & Rp3300000000000.00 & Rppo.0338.860.000.000 & 27-Feb-09] & $100,0000 \% \%$ & $267,88^{\circ}$ \\
\hline
\end{tabular}

Sumber : Manajemen Investasi Syariah - UI - EKS XVI

Pasar modal syariah telah diluncurkan pada 14 Maret 2003. Muncul harapan bahwa pasar modal yang didasari prinsip-prinsip syariah dapat berkembang lebih besar lagi. Pasar 
modal syariah diharapkan dapat mendorong pertumbuhan institusi-institusi (lembaga keuangan) syariah dan instrumen-instrumen syariah. Salah satu instrumen syariah yang diperkirakan akan berkembang pesat adalah obligasi syariah. Memang terdapat keterkaitan yang erat dalam upaya pengembangan pasar modal syariah ini. Pasar,instrumen, dan institusi menjadi komponen yang saling mendukung dalam sistem keuangan. Satu institusi akan membutuhkan pasar, instrumen, dan institusi lainnya. Ketika bank syariah dikembangkan, muncullah kebutuhan untuk membuat pasar uang syariah. Pada saat reksa dana syariah dimunculkan, perlu instrumen halal untuk penyaluran penempatan portfolio-nya. Demikian juga dengan asuransi dan dana pensiun syariah. Lembaga keuangan syariah ini memerlukan bank syariah, membutuhkan pasar modal syariah dengan saham halal dan obligasi syariahnya. Ketika suatu emiten yang tercatat di bursa ingin dikatakan tergolong syariah, boleh jadi emiten tadi memerlukan obligasi syariah sebagai pendanaan alternatifnya.

\section{Perbandingan Obligasi Konvensional dan Obligasi Syariah (Sukuk)}

Pengertian obligasi syariah berbeda dengan obligasi konvensional. Semenjak ada konvergensi pendapatbahwa bunga adalah riba, maka instrumen-instrumen yang punya komponen bunga (interest-bearing instruments) ini keluar dari daftar investasi halal. Karena itu, dimunculkan alternatif yangdinamakan obligasi syariah.Merujuk kepada Fatwa Dewan Syari' ah Nasional No: 32/DSN-MUI/IX/2002, "Obligasi Syariahadalah suatu surat berharga jangka panjang berdasarkan prinsip syariah yang dikeluarkanEmiten kepada pemegang Obligasi Syari'ah yang mewajibkan Emiten untuk membayar pendapatan kepada pemegang Obligasi Syari'ah berupa bagi hasil/margin/fee, serta membayar kembali dana obligasi pada saat jatuh tempo".Pada awalnya, penggunaan istilah "obligasi syariah" sendiri dianggap kontradiktif. Obligasi sudahmenjadi kata yang tak lepas dari bunga sehingga tidak dimungkinkan untuk di- syariah-kan.Namun sebagaimana pengertian bank syariah adalah bank yang menjalankan prinsip syariah,tetap menghimpun dan menyalurkan dana, tetapi tidak dengan dasar bunga, demikian jugaadanya pergeseran pengertian pada obligasi. Mulanya dikenal sebagai instrumen fixed incomekarena memberikan kupon dengan bunga tetap (fixed) sepanjang tenornya. Kemudiandikembangkan juga obligasi dengan kupon bunga mengambang (floating) sehingga bunga yangditerima pemegang obligasi tidak lagi tetap. Dalam hal obligasi syariah, kupon yang diberikantidak lagi berdasarkan bunga, tetapi bagi hasil atau margin/fee.Menarik untuk memperhatikan bahwa Fatwa Dewan Syari'ah Nasional No: 32/DSN- MUI/IX/2002tersebut memberikan pertimbangan awal bahwa obligasi yang selama ini (konvensional)didefinisikan masih belum sesuai dengan syariah. Karenanya, 
obligasi yang dibenarkan menurutsyariah yaitu obligasi yang berdasarkan prinsip syariah. Obligasi konvensional adalah surat tanda hutang perushaan kepada peusahaan obligasi (bondholder) dan perusahaan harus membayar bunga (coupon) secara periodic serta sejumlah nominal ketika jatuh tempo kepada pemegang obligasi.

Obligasi syariah dalam bahasa Inggris disebut juga Islamic Bond dan di beberapa Negara lain terutama Timur Tengah dikenal dengan nama Sukuk. Sukuk merupakan suatu surat berharga jangka panjang ber-dasarkan prinsip syariah yang diterbitkan emiten baik oleh Pemerintah maupun perusahaan kepada pemegang obligasi syariah dan mewajibkan emiten untuk membayar pendapatan (bagi, hasil, margin, fee) dan membayar kembali dan obligasi pada saat jatuh tempo.(Fatwa DSN,2004)

Tabel 1. Perbandingan Obligasi Konvesional dengan Obligasi Syariah (Sukuk)

\begin{tabular}{|l|l|l|}
\hline \multicolumn{1}{|c|}{ Kriteria } & \multicolumn{1}{|c|}{ Obligasi Konvensional } & \multicolumn{1}{c|}{ Sukuk } \\
\hline \multirow{2}{*}{ Penerbit } & $\begin{array}{l}\text { 1. Pemerintah } \\
\text { 2. Korprat }\end{array}$ & $\begin{array}{l}\text { 1. Pemerintah } \\
\text { 2. Korprat }\end{array}$ \\
\hline \multirow{2}{*}{ Metode Penerbitan } & $\begin{array}{l}\text { 1. Lelang } \\
\text { 2. Book building }\end{array}$ & $\begin{array}{l}\text { 1. Lelang } \\
\text { 2. Book building }\end{array}$ \\
\cline { 2 - 3 } Sifat Instrumen & Pengakuan Utang & $\begin{array}{l}\text { 3. Private Placement } \\
\text { Penyertaan atas suatu asset }\end{array}$ \\
\hline Tipe Investor & Konvensional & $\begin{array}{l}\text { 1.Konvensional } \\
\text { 2. Syariah }\end{array}$ \\
\hline $\begin{array}{l}\text { Keuntungan } \\
\text { investor }\end{array}$ & $\begin{array}{l}\text { Bunga/Kupon } \\
\text { Capital Gain }\end{array}$ & $\begin{array}{l}\text { Bagi hasil, Margin, Imbalan } \\
\text { fee })\end{array}$ \\
\hline $\begin{array}{l}\text { Dokumen } \\
\text { diperlukan }\end{array}$ & Dokumen pasar modal & $\begin{array}{l}\text { Dokumen pasar modal } \\
\text { Dokumen Syariah }\end{array}$ \\
\hline Underling Asset & Tidak Perlu & Perlu \\
\hline $\begin{array}{l}\text { Penggunaan hasil } \\
\text { penjualan (proceed })\end{array}$ & Bebas & Harus sesuai dengan Syariah \\
\hline Lembaga Terkait & Trustee,Agen Pembayar & SPV, Trustee, Agen Pembayaran \\
\hline $\begin{array}{l}\text { Pengesahan Dewan } \\
\text { Syariah (DSN) }\end{array}$ & Tidak Perlu & Perlu \\
\hline
\end{tabular}

Sumber: Laksono (2007)

Tabel 2: Ringkasan Perbandingan Obligasi dan Sukuk

\begin{tabular}{|l|r|r|r|}
\hline & $\begin{array}{c}\text { Obligasi } \\
\text { Konvensional }\end{array}$ & Syariah Mudharabah & Syariah Ijarah \\
\hline Akad (Transaksi) & Tidak Ada & Mudharabah (Bagi Hasil) & Ijarah (Sewa/Lease) \\
\hline Jenis Transaksi & - & Uncertainty Contract & ertainty Contract \\
\hline
\end{tabular}




\begin{tabular}{|l|r|r|r|} 
Sifat & Surat Hutang & Investasi & Investasi \\
\hline Harga Penawaran & $100 \%$ & $100 \%$ & $100 \%$ \\
\hline $\begin{array}{l}\text { Pokok Obligasi saat } \\
\text { Jatuh Tempo }\end{array}$ & $100 \%$ & $100 \%$ & $100 \%$ \\
\hline Kupon & Bunga & Pendapatan/Bagi Hasil & Imbalan/Fee \\
\hline Return & Float/Tetap & $\begin{array}{r}\text { Indikatif berdasarkan } \\
\text { Pendapatan/Income }\end{array}$ & Ditentukan sebelumnya \\
\hline $\begin{array}{l}\text { Fatwa Dewan Syariah } \\
\text { Nasional }\end{array}$ & Tidak Ada & No. 33/DSN-MUI/IX/2002 & $\begin{array}{r}\text { No: 41/DSN- } \\
\text { MUI/II/2004 }\end{array}$ \\
\hline Jenis Investor & Konvensional & Syariah/Konvensional & Syariah/Konvensional \\
\hline
\end{tabular}

Sumber: Achsien (2004)

\section{Dasar Hukum Obligasi Syariah (Sukuk) di Indonesia}

Obligasi syariah (Sukuk) yang terbit di Indonesia harus memenuhi persyaratan dan mengikuti aturan yang berlandaskan (Briefcase book, 2005), yaitu :

1. Pendapat ulama tentang keharaman mendapat bunga (Interest)

2. Pendapat para ulama tentang keharaman obligasi yang penghasilannya berbantuk bunga (kupon)

3. Pendapat ulama tentang obligasi syariah yang menggunakan prinsip Mudharabah, Ijarah, Musyawarah, Murabahah, Istishna, dan Salam

4. Fatwa dewan Syariah Nasional (DSN) No. 20 DSN/IV/2001 mengenai pedoman pelaksanaan Investasi Reksa Dana Syariah

5. Fatwa Dewan Syariah Nasional Nomor: 32/DSN-MUI/IX/2002 tentang Obligasi Syariah

6. Obligasi Syariah Mudharabah (No.33/DSN-MUI/IX/2002)

7. Pasar Modal dan Pedoman Umum Penerapan Syariah di Bidang Pasar Modal (No:40/DSN-MUI/IX/2003)

Dewan Syariah Nasional MUI menyatrakan bahwa agar obligasi dapat diterbitkan sesuai dengan prinsip syariah, Dewan Syari' ah Nasional memandang perlu menetapkan fatwa mengenai hal tersebut untuk dijadikan pedoman.

1. Firman Allah SWT, QS. Al-Ma'idah [5]:1: 
"Hai orang-orang yang beriman, penuhilah aqad-aqad itu ${ }^{[388]}$. Dihalalkan bagimu binatang ternak, kecuali yang akan dibacakan kepadamu. (Yang demikian itu) dengan tidak menghalalkan berburu ketika kamu sedang mengerjakan haji. Sesungguhnya Allah menetapkan hukum-hukum menurut yang dikehendaki-Nya."

2. Firman Allah SWT, QS. Al-Isra’ [17]: 34:

"Dan janganlah kamu mendekati harta anak yatim, kecuali dengan cara yang lebih baik (bermanfaat) sampai ia dewasa dan penuhilah janji; sesungguhnya janji itu pasti diminta pertanggungan jawabnya."

3. Firman Allah SWT., QS. Al-Baqarah [2]: 275:

"Orang yang makan (mengambil) riba tidak dapat berdiri melainkan seperti berdirinya orang yang kemasukan syaitan lantaran (tekanan) penyakit gila. Keadaan mereka yang demikian itu adalah disebabkan mereka berkata (berpendapat), sesungguhnya jual beli itu sama dengan riba, padahal Allah telah menghalalkan jual beli dan mengharamkan riba. Orang yang telah sampai kepadanya larangan dari Tuhannya, lalu terus berhenti (dari mengambil riba), maka baginya apa yang telah diambilnya dahulu (sebelum datang larangan); dan urusannya (terserah) kepada Allah. Orang yang mengulangi (mengambil riba), maka orang itu adalah penghuni-penghuni neraka; mereka kekal di dalamnya."

Menurut pakar keuangan Syariah seperti A. Karim, bahwa tahun 2007 bagi keuangan syariah yang ditandai akan bermunculan produk syariah baru yang diluncurkan perbankan syariah maupun pasar modal syariah. Di perbankan syariah akan diluncurkan KP syariah , Islamic Card dan Trade finan Syariah serta diperkirakan 8 sampai 11 bank akan membuka Usaha-Usaha Syariah (UUS) sedangkan pasar modal akan segera diterbitkan Obligasi Syariah Negara atau Sukuk Berharga Syariah Negara (SBSN).

\section{Perkembangan Obligasi Syariah (Sukuk)}

Sampai akhir tahun 2006, pertumbuhan Sukuk di Indonesia masih sangat lambat, hal ini terlihat jumlah Sukuk yang diterbitkan pada tahun 2003 sebanyak 5 kemudian tahun 2004 bertambah 7 Sukuk dan pada tahun 2005 hanya bertambah 3 Sukuk. Pada tahun 2006 hanya 1 Sukuk yang diterbitkan dengan menggunakan akad Ijarah oleh PLN senilai 200 Milyar. Jadi sampai bulan februari 2007, Indonesia baru memiliki 17 Sukuk yang semuanya diterbitkan oleh korporasi dengan menggunakan dua jenis akad, yakni akad Mudharabah dan akad Musyarakah. Oleh sebab itu hanya terdapat dua tipe Sukuk yaitu Obligasi Syariah Mudharabah (OSM) dan Obligasi Syariah Ijarah (OSI).

Dari 17 Obligasi syariah yang di terbitkan korporasi tersebut, 7 Obligasi Syariah dengan akad Mudharabah dengan total nilai Rp 815 Milyar dan 10 Obligasi syariah yang menggunakan akad Ijarah sebesar Rp 1.394 Milyar sehinggatotal nilai Obligasi syariah di Indonesia sebesar Rp 2,209 Trilyun 
(BES,2007). Pada awal tahun 2007 ini total nilai obligasi korporasi konvensional yang telah diterbitkan di Indonesia Sebanyak Rp 96,13 Trilyun sedangkan total Obligasi syariah baru mencapai Rp 2,209 Trilyun. Jadi sampai saat ini pasar obligasi syariah masih kecil jika dibandingkan dengan obligasi Syariah Negara (Government Islamic Bond) belum diterbitkan dan memiliki nilai emisi yang besar.

\section{PERKEMBANGAN PENERBITAN SUKUK (OBLIGASISYARIAH) DAN SUKUK (OBLIGASISYARIAH) YANG MASIH BEREDAR (OUTSTANDING)}

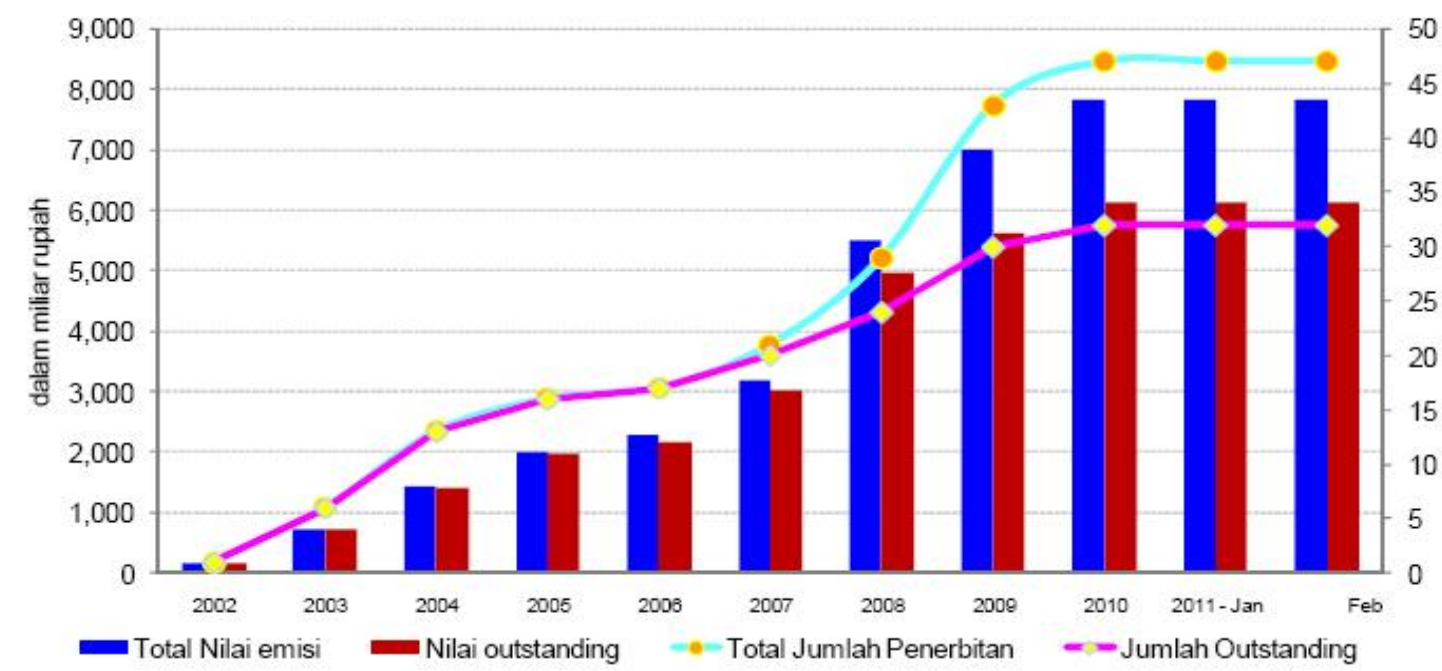

Sumber : Statistik Pasar Modal Syariah, Feb 2011

\section{Mengapa Obligasi Syariah?}

Dari sisi pasar modal, penerbitan obligasi syariah muncul sehubungan dengan berkembangnya institusi-institusi keuangan syariah, seperti asuransi syariah, dana pensiun syariah, dan reksa dana syariah yang membutuhkan alternatif penempatan investasi. Menariknya, investor obligasi syariah tidak hanya berasal dari institusi-institusi syariah saja, tetapi juga investor konvensional. Produk syariah dapat dinikmati dan digunakan siapa pun, sesuai falsafah syariah yang sudah seharusnya memberi manfaat (maslahat) kepada seluruh semesta alam. Investor konvensional akan tetap bisa berpartisipasi dalam obligasi syariah, jika dipertimbangkan bisa memberi keuntungan kompetitif, sesuai profil risikonya, dan juga likuid. Sementara obligasi konvensional, investor base-nya justru terbatas karena investor syariah tidak bisa ikut ambil bagian di situ. (Achsien, 2000)

Bagi emiten, menerbitkan obligasi syariah berarti juga memanfaatkan peluangpeluang tertentu. Emiten dapat memperoleh sumber pendanaan yang lebih luas, baik investor 
konvensional maupun syariah. Selain itu, struktur obligasi syariah yang inovatif juga memberi peluang untuk memperoleh biaya modal yang kompetitif dan menguntungkan. Tetapi, sebagai catatan, tidak semua emiten dapat menerbitkan obligasi syariah. Untuk menerbitkan Obligasi Syariah, beberapa persyaratan berikut yang harus dipenuhi:

1. Aktivitas utama (core business) yang halal, tidak bertentangan dengan substansi Fatwa No: 20/DSN-MUI/IV/2001. Fatwa tersebut menjelaskan bahwa jenis kegiatan usaha yang bertentangan dengan syariah Islam di antaranya adalah: (i) usaha perjudian dan permainan yang tergolong judi atau perdagangan yang dilarang; (ii) usaha lembaga keuangan konvensional (ribawi), termasuk perbankan dan asuransi konvensional; (iii) usaha yang memproduksi, mendistribusi, serta memperdagangkan makanan dan minuman haram; (iv) usaha yang memproduksi, mendistribusi, dan atau menyediakan barang-barang ataupun jasa yang merusak moral dan bersifat mudarat.

2. Peringkat Investment Grade: (i) memiliki fundamental usaha yang kuat; (ii) memiliki fundamental keuangan yang kuat; (iii) memiliki citra yang baik bagi publik. Keuntungan tambahan jika termasuk dalam komponen Jakarta Islamic Index (JII).

Rekapitulasi Perdagangan Efek Tahun 2009

\begin{tabular}{|l||l|r|r|}
\hline No. & \multicolumn{1}{|c|}{ Instrumen } & \multicolumn{1}{|c|}{$\begin{array}{l}\text { Total Nilai } \\
\text { Pelaporan }\end{array}$} & $\begin{array}{c}\text { Rata-rata Nilai } \\
\text { Pelaporan Harian }\end{array}$ \\
\hline \hline 1 & Surat Berharga Negara $*)$ & $793.687,29$ & $3.320,87$ \\
\hline 2 & Surat Hutang Negara **) & $743.870,36$ & $3.112,43$ \\
\hline 3 & Obligasi Republik Indonesia & $43.539,47$ & 182,17 \\
\hline 4 & Sukuk Negara Ritel & $6.277,47$ & 369,26 \\
\hline 5 & Obligasi Korporasi Rupiah $* * *)$ & $36.049,58$ & 150,84 \\
\hline 6 & Obligasi syariah \& Sukuk Korporasi & $2.332,18$ & 9,76 \\
\hline
\end{tabular}

Sumber : Manajemen Investasi Syariah - UI - EKS XVI

Penerbitan Sukuk Negara (SBSN) akan memepercepat tumbuhnya keuangan syariah karena diterbitkan oleh pemerintah yang merupakan instrument keuangan dengan tanpa resiko (clear risk) disamping memiliki nilai emisi besar dibandingkan Sukuk koperasi. Kondisi ini akan memberi peluang kepada investor institusi untuk menginvestasikan dananya dengan jumlah yang lebih besar. Investor institusi tersebut seperti perusahaan asuransi, 
perusahaan dan pension serta perbankan syariah yang kelebihan dana, yang selama ini hanya di investasikan pada saham, obligasi syariah korporasi , Reksadana serta Surat Wadiah Bank Indonesia (SWBI).

Di sisi lain, penerbitan Sukuk atau SBNS ini memiliki peran yang strategis bagi pemerintah dan sangat dinantikan para pelaku pasar keuangan syariah kerena beberapa alasan (Karim, 2004):

1. Sebagai diversifikasi sumber pembiayaan APBN dan mengurangi resiko utang pemerintah.

2. Merupakan sumber pembiayaan bagi pemerintah untuk membangun infrastruktur seperti yang telah dilakukan oleh Malaysia.

3. Merupakan benckmark bagi instrument keuangan stariah baik pasar modal domestic maupun internasional.

4. Sebagai alternative investasi bagi investor individu dan institusi seperti perbankan, asuransi, dana pensiun yang kelebihan likuiditasnya yang selama ini diinvestasikan ke SBI dan SWBI.

5. Memperkuat dan meningkatkan peran system keuangan berbasis syariah didalam negeri melalui pengembangan alternative instrument investasi.

6. Mendorong pertumbuhan dan pengembangan keuangan syariah di Indonesia.

Berdasarkan alasan-alasan tersebut sudah seharusnya Pemerintah mengiring percepatan proses penerbitan Sukuk Negara (SBSN)

\section{Surat Berharga Syariah Negara (SBSN)}

Selain Sukuk yang diterbitkan oleh perusahaan (corporate Islamic Bond), Pemerintah Indonesia juga perlu menerbitkan Obligasi Syariah Negara (Sukuk Negara) yang diberi nama Surat Berharga Syariah Negara (SBSN), baik yang akan dijual untuk investor dalam negeri dengan mata uang USD yang disebut Islamic Sovereign Bond. Penerbitan Sukuk Negara (SBSN) ini memiliki peran yang strategis karena untuk mendapatkan dana dengan menggunakan prinsip-prinsip Syariah, menyediakan kesempatan berinvestasi secara Syariah di Pasar Sekunder, menambah alternative investasi bagi lembaga keuangan yang kelebihan likuiditas, juga menciptakan benchmaking yang digunakan untuk mengukur rating resiko Negara (Bakar, 2005)

Untuk menerbitkan Sukuk Negara berbeda dengan penerbitan Sukuk Korporasi karena mekanisme penerbitan Sukuk khususnya Islamic Sovereign Bond harus melalui Special Purpose vehicle (SPV) yaitu suatu badan yang dibentuk Pemerintah yang berwenang untuk menerbitkan Sukuk Negara berdasarkan Undang-Undang yang dibuat oleh Pemerintah. 


\section{Dampak Sukuk Negara (SBSN) bagi Lembaga Keuangan Syariah}

Pertumbuhan Lembaga Keuangan Syariah (LKS) seperti Pasar Modal, Pasar Uang, Perbankan, Asuransi serta Reksadana saling mendukung karena pihak satu dengan lainnya saling bergantung. Artinya semakin tinggi pertumbuhan LKS semakin tinggi kebutuhan akan keanekaragaman produk keuangan berbasis syariah sebagai alternative investasi. Jadi semakin cepat pertumbuhannya maka semakin perlu perusahaan atau pemerintah mengeluarkan produk keuangan syariah yang baru sebagai alternatif investasi. Oleh sebab itu semakin tinggi kebutuhan terbitnya Sukuk Negara sebagai alternatif investasi karena memiliki nilai emisi yang besar juga memberikan resiko yang lebih rendah daripada Sukuk yang diterbitkan oleh perusahaan (corporate).

Bagi perusahaan sekuritas yang menawarkan Reksadana, produk SBSN sangat penting sebagai produk tambahan dalam membentuk portofolio investasi yang lebih menguntungkan yang akan ditawarkan kepada investor. Selain itu SBSN digunakan sebagai benchmark dari kinerja portofolio yang tersedia.namun bagi perbankan, perusahaan Asuransi serta lembaga Dana Pensiun maka SBSN akan dimanfaatkan sebagai alternatif investasi atas kelebihan likuiditasnya. Selain itu perbankan akan menggunakan SBSN sebagai benchmark dari imbal hasil (return) yang ditawarkan ke nasabah. Jadi semakin tinggi kepentingan terhadap penerbitan Sukuk Negara (SBSN) Karena akan mempercepat tumbuhnya pasar keuangan syariah di Indonesia. Sampai awal tahun 2007 perkembangan Lembaga keuangan Syariah seperti Perbankan, Asuransi dan Reksadana syariah begitu pesat.

\section{KESIMPULAN}

Sukuk/obligasi syaraih memiliki keunggulan dibandingkan obligasi konvesional yakni: (1) penggunaan dana dari hasil penerbitan Sukuk sejenak awal sudah jelas untuk mengembangkan proyek tertentu (2) risiko Sukuk terdefinisi sejak awal oleh proyek yang di biayai (3) tuntutan kedisiplinan penggunaan dana $S u k u k$, karena sudah jelas sifat peruntukan penggunan dana untuk proyek tertentu. Hal tersebut sangat besar peranannya untuk membiayai proyek pembangunan infrastruktur seperti pembangunan pelabuhan, bandara, jalan atau lainya disamping untuk membiayai proyek sosial seperti pendidikan, atau rumah sakit.

Saat ini, potensi permintaan Sukuk cukup tinggi baik dari investor local maupun investor luar negeri. Namun kenyataannya saat ini produk obligasi syariah sedikit yang ditawarkan dan obligasi syariah tersebut ditawarkan dengan mata uang rupiah (Rp) belum 
yang menggunakan mata uang dolar (USD). Bagi penduduk Indonesia khususnya yang masyarakatnya mayoritas muslim, hal ini dengan sendirinya memiliki potensi yang sangat besar terhadap pasar Sukuk (Islamic Bond) karena sebagai alternative bagi investor muslim untuk memilih produk pasar modal yang sesuai dengan prinsip syariah.

Sukuk pun dapat digunakan sebagai pendorong pengembangan instrument pasar modal syariah di Indonesia karena obligasi syariah ini sangat diperlukan untuk investasi lembaga perbankan syariah yang kelebihan likuiditasnya, Reksa Dana Syariah, Asuransi Syariah, Lembaga Dana Pensiun maupun investor individual dan institusi lainya yang tertarik berinvestasi pada Sukuk. Juga, memberikan edukasi kepada investor lokal untuk memahami seluk beluk Sukuk sehingga akan mengalihkan investasinya dari obligasi konvesional ke obligasi syariah (Sukuk) yang akhirnya akan menumbuhkan pasar modal syariah di Indonesia semakin pesat lagi. Sehingga permintaan Sukuk pun saat ini sangat tinggi, mengingat banyaknya dana dari Timur Tengah yang menganggur yang mencari instrument pasar modal syariah yang cocok dengan pemahaman mereka tentang jenis Sukuk yang akan ditawarkan. 


\section{DAFTAR PUSTAKA}

Abdul Gani, Badlisyah, "Financial Analysis On Islamic Sovereign Bond (Pricing, Timing, Risk Assesment)",Round-table Discussion on International Islamic Sovereign Bond (Sukuk), Jakarta, 23-24 September 2004

Abubakar, Ariayana,dkk, Proceeding Round-Table Discussion On International Islamic Sorvereign Bond (Sukuk), Jakarta, 23-24 September 2004

Achsein, Iggi H, "Mengembangkan Pasar Modal Syariah melalui pengawasan dan Regulasi yang Efektif dan Mendukung", WorkShop Shariah Economic Days (Second), Februari 2004

Achsein, Iggi H,'Investasi Syariah Di Pasar Modal: Menggagas Konsep dan Praktek Manajemen Manajemen Portofolio Syariah, "PT Gramedia Pusaka Utama, Jakarta, 2000

Adam, Nathif Jama, "A Panacea for Conference On Islamic Economic Banking and Finance, Jakarta 21-24 Nopember 2005

Antonio, Muhammad Syafi'i, "Bank Syariah Dari Teori Ke Praktek", Gema Insani Press, Jakarta, 2001

Ayub, Muhammad, "Securitization, Sukuk and Fund Management Potential to be Realized by Islamic Financial Instutitions", 6 TH International Conference On Islamic Economic Banking and Finance, Jakrta 21-24 Nopember 2005

Aziz Setawan \& Handi Risza Idris, "Sukuk untuk Pembiayaan Infrastruktur : Kendala dan Beberapa Langkah Strategis” Majalah modal Edisi 41, Tahun 2006

Bakar, Mohd. Daud,"Syariah Compliance on International Islamic Sovereign Bond Mechanism" Table Discussion International Islamic Bond, 2004

Briefcase Book, Konsep Dasar Obligasi Syariah, Edukasi Profesional Syariah, 2006

Bursa Efek Surabaya (BES), helpdesk, 2007

Data Statistik Direktorat Perbankan Syariah (DPbs) BI, Des 2006

Fatwa Dewan Syariah Nasional N0. 32/DSN-MUI/IX/2002

Indrawati, Sri Mulyani, "Menyongsong penerbitan Sukuk Negara", Seminar Islamic Finance Outlook 2007, 16 February 2007

Iswahjudi, A. Karim,” Legal Aspect on Issuing Islamic Sovereign Bond, Round Table. 2004

Laksono, Agus.P., "Sukuk : Alternatif Instrumen Investasi dan Pembiayaan ,"WorkShop Shariah Economic Days (Second), 14 Februari 2007

Majalah Asuransi Takafu pada tahun 1994

Majalah Modal,"Pilih Mudharabah atau Ijarah", No. 23 Edisi Desember, 2004

Manajemen Investasi Syariah. Makalah seminar. Universitas Indonesia, EKS XVI

Statistik Pasar Modal Syariah, Februari 2011 

